\title{
SPIRITUAL WELL-BEING OF PATIENTS WITH CANCER OF GYNAECOLOGI
}

\author{
Sellyan Septiani Berly ${ }^{1}$, Efri Widianti ${ }^{2}$, Ermiati $^{3}$ \\ ${ }^{\mathbf{1 , 2 , 3}}$ Fakultas Keperawatan Universitas Padjadjaran, Bandung Jawa Barat \\ Correspondence: efri.widianti@unpad.ac.id
}

\begin{abstract}
Gynaecological cancer is a women's disease with a high incidence. Problems that occur in gynaecological cancer patients include physical, psychosocial, and spiritual aspects. However, spiritual well-being in gynaecological cancer patients is ignored so that it is not clearly seen how the condition of patients' spiritual well-being. This study aimed to describe the spiritual well-being of gynaecological cancer patients in a referral hospital in Bandung. The design of this study used quantitative descriptive with a total sample method. The number of samples was 41 patients. The study was conducted for one month from June to July, the sampling technique used was accidental sampling. The instrument in this study used the Spiritual Index of Well-being (SIWB). Data were analysed using frequency distributions, averages, and percentages. The results showed that $68.29 \%$ of respondents had a high level of spiritual well-being, and $21.79 \%$ had a low level of spiritual well-being. The self-efficacy sub-variable had an average value of 19.46 lower than the life-scheme sub-variable of 22.29. The item that has the highest value is "In this world, I don't know where I feel comfortable" and the item that has the lowest value is "There's not much I can do to help myself". The conclusion of the results of this study is that most respondents have a high level of spiritual well-being. Self-efficacy is a sub-variable with the lowest average value.
\end{abstract}

Keywords: gynaecological cancer, life-scheme, self-efficacy, spiritual

\section{INTRODUCTION}

Cancer is a disease that characterized by the growth of uncontrolled abnormal cells caused by genetic mutations of cellular DNA. Cancer that occurs in the female reproductive organs include cervical cancer, ovarian cancer, and vaginal cancer (Suddarth, 2013). In 2012, cancer caused around 8.2 million deaths, and breast cancer became one of the largest causes of cancer deaths each year (International Agency for Research on Cancer, 2012). In Indonesia, the prevalence of cancer reached $1.4 \%$ in the population of all ages in 2013, and breast and cervical cancers were among the highest. Cancer prevalence in West Java reached 1.0\%. Estimates of cervical and breast cancer sufferers in 2013 in West Java were 15,635 and 6,701 people (Riskesdas, 2013).

The problems experienced by gynaecological cancer patients are very complex including physical, psychological, social, and spiritual aspects. However, spiritual aspects are still very 
rarely considered by health workers, especially nurses. This is an evidence in a study conducted by Vance (2001) that only $34.6 \%$ of nurses conduct studies on spiritual aspects. Spiritual wellbeing is very important to study. Patients with terminal illness need spiritual as healing, which means that spiritual becomes a healing source for patients with terminal illness. In addition, patients with cancer who have good spiritual will find peace in their lives, and they will be better prepared to face the worst possibilities, including death. (Mok, Wong, Wong, 2009; Puchalski, 2009). Good spirituality in cancer patients can help patients face life's challenges, especially during long treatment. Even spirituality can improve the quality of life of patients (Rippentrop et al, 2006 in Richardson, 2012).

Another problem experienced by cancer patients that are influenced by the patient's spiritual state is self-efficacy. Individuals who have been diagnosed with cancer will experience various kinds of negative emotions such as withdrawing, refusing treatment, or not taking chemotherapy. Decisions and beliefs or self-efficacy in cancer patients are very influential in the treatment process and ultimately have an impact on the healing process (Daleeman and Frey, 2007).

The role of nurses in providing nursing care to the spiritual aspects, namely accompanying and listening to the complaints of patients. As a motivator, nurses can also involve the family or the people closest to the patient to provide spiritual support, besides providing facilities to patients to communicate with God can also affect the level of their spiritual well-being (Perry and Potter, 2005).

Data from the medical records of a referral hospital in Bandung showed that the number of patients that diagnosis gynecological cancer was 480 patients in 2015 . The highest case was cervical cancer $(n=212)$, the second most case was uterine cancer, 205 cases. The results of a preliminary study related to nursing interventions in a cancer ward showed that nursing care 
activities regarding spiritual support for patients were limited. The researcher interviewed 10 patients, the interview found that most patients were afraid of the symptoms of the disease that arises, and the therapy that will be carried out. When talking about a patient's illness and how the patient understands life with his illness, three patients are seen crying and explaining that they feel they have a lot of sins so that God gives this disease. Long treatment makes the patient separate from his family so that patients feel anxious and often feel hopeless to undergo treatment. Most patients claim that they feel helpless to live. But there are also patients who claim that they feel closer to their Lord and interpret life better after have diagnosed with cancer.

The condition of an individual's spiritual well-being is very dynamic, subjective, and emotive so that at any time the condition may change significantly. This study aimed to describe the spiritual well-being of gynecological cancer patients in a referral hospital in Bandung.

\section{METHODS}

This type of research is a descriptive quantitative study. The variables in this study were spiritual well-being in gynecological cancer patients divided into two sub-variables, which are selfefficacy and life-scheme. The population in this study were gynecological cancer patients in a referral hospital in Bandung. Sample selection using an accidental sampling technique to obtain 41 patients with gynecological cancer for 1 month. The instrument used in this study was the Spiritual Index of Well-Being to measure the level of spiritual well-being in gynecological cancer patients that developed by Daaleman and Frey (2007). In this instrument, there are 12 items with two subscales, self-efficacy subscale, and life-scheme subscale, each answer to the question given five rankings, from 1 to 5, 1 means strongly agree and 5 states strongly disagree.

The validity value of this instrument is 0.87 . The reliability value of the Spirituality Index of 
Well-Being questionnaire has Cronbach alpha 0.867 which shows this questionnaire is reliable to use (Nurhalimah, 2015). Data were analyzed using frequency distributions, averages, and percentages.

\section{RESULTS}

The results showed that 28 respondents $(68.29 \%)$ had a high level of spiritual well-being and the remaining 13 respondents $(32.71 \%)$ had a low level of spiritual welfare. Then the data points to the majority of respondents having a high level of spiritual well-being (Table 1).

From table 2, it was found that 22 respondents (53.66\%) had high self-efficacy and 19 respondents $(46.34 \%)$ had low levels of self-efficacy. In the life-scheme dimension, it has the same percentage as the self-efficacy dimension which is 22 respondents $(53.66 \%)$ have a high life-scheme rate and 19 respondents (46.34) have a low life-scheme level.

Table 1. Spiritual Welfare Level of Gynaecological Cancer Patients $(n=41)$

\begin{tabular}{llll}
\hline No. & Spiritual well-being & Frequency $(f)$ & Percentage $(\%)$ \\
\hline 1. & Low & 13 & $31,71 \%$ \\
2. & High & 28 & $68,29 \%$ \\
\hline
\end{tabular}

Table 2 Spiritual Welfare Level of Gynaecological Cancer Patients Based on Sub Variables $(\mathbf{n}=41)$

\begin{tabular}{ccccc}
\hline No. & Sub Variable & Frequency $(\boldsymbol{f})$ & $\begin{array}{c}\text { Percentage } \\
(\boldsymbol{\%})\end{array}$ & Average \\
\hline & Self-Efficacy & 19 & 46,34 & \\
$\mathbf{1}$ & Low & 22 & 53,66 & 19,46 \\
$\mathbf{2}$ & High & & & \\
& & & & 22,29 \\
& Life-Scheme & 19 & 46,34 & \\
$\mathbf{1}$ & Low & 22 & 53,66 & \\
\hline
\end{tabular}


Table 3 Spiritual Welfare of Gynaecological Cancer Patients Based on Sub Variables $(\mathrm{n}=41)$

\begin{tabular}{|c|c|c|c|}
\hline No. & Item Question & Total & Average \\
\hline 1 & There is not much I can do to help myself & 115 & 2,80 \\
\hline 2 & $\begin{array}{l}\text { There is no way out that I can solve from what I } \\
\text { started }\end{array}$ & 147 & 3,58 \\
\hline 3 & I can't understand what the problem is with me & 133 & 3,24 \\
\hline 4 & I feel burdened when I face difficulties or personal & 126 & 3,02 \\
\hline 5 & $\begin{array}{l}\text { problems } \\
\text { I don't know how to start solving problems }\end{array}$ & 148 & 3,60 \\
\hline 6 & I don't do much to make a difference in my life & 129 & 3,14 \\
\hline 7 & I have not found the purpose of life & 145 & 3,53 \\
\hline 8 & I don't know who I am, where I am, or where I go. & 161 & 3,92 \\
\hline 9 & I have no purpose in life & 147 & 3,58 \\
\hline $\begin{array}{l}10 \\
11\end{array}$ & $\begin{array}{l}\text { In this world, I don't know where I feel } \\
\text { comfortable }\end{array}$ & $\begin{array}{l}164 \\
158\end{array}$ & $\begin{array}{l}4,00 \\
3,85\end{array}$ \\
\hline 12 & I do not understand the meaning of life & 135 & 3,29 \\
\hline
\end{tabular}

Based on table 3, it is found that item number one on the sub-variable of self-efficacy has the lowest average score of 2.80 . The highest average score was in item number ten in the subvariable life-scheme with a value of 4.00 .

\section{DISCUSSION}

Based on the results, the level of patient's spiritual well-being varies between high and low. Individual spirituality is influenced by several factors including the stage of development, family, ethnic and cultural background, previous life experiences, and crises and changes (Taylor, Lillis \& Le Mone (1997), and Craven \& Himle (1996) in (Hamid, 2009). According to 
the theory that the diagnosis of terminal diseases is diseases that cause disability/pain, loss of body parts or functions, therapy/treatment including surgical advice, and dietary restrictions will affect individual spirituality (Kozier et. Al., 2004). Puchalski (2001 ) mentions that spiritual is a source of hope and healing for individuals. If the individual's spiritual well-being is not achieved maximally, the physical and psychosocial aspects will not be achieved maximally. The results of the research have shown that most respondents have high levels of spiritual well-being. This is in line with the research conducted by Bekelman et al (2009), the study stated that the level of spiritual well-being in cancer patients has a score close to the maximum number, which means the level of spiritual well-being is high in cancer patients.

High levels of spiritual well-being can be caused by several factors, such as family support. All respondents have Sundanese cultural backgrounds. Previous research stated that eastern society including Indonesia with one of its cultures namely Sundanese had traditional values such as familism, family as central, interdependence, and maintaining harmony (Friedman, Bowden, and Jones, 2003). Spiritual support from the family is needed by the patient, the results of the study prove that the patient is always accompanied by their family, whether from a husband, child, or other family members. The patient feels more strength and is motivated by their family to carry out all the treatments.

The physical condition of the respondents when they fill out the questionnaire was stable. Respondents did not complain of any physical disturbances. Most patients who are undergoing treatment are waiting to be performed chemotherapy and surgery so that there is no effect on the treatment they have undergone. This can be one of the factors at least respondents who have a low level of spiritual well-being. The sub-variables: self-efficacy and life-scheme have the majority of high scores which are $46.34 \%$ has a low level and a high level of $53.66 \%$. Indonesian 
cultures that have high religiosity also influence the high value of sub-variables of life-scheme. As a study conducted by Hasnani (2012) on 74 cervical cancer patients when interviewed, they said that this disease was a trial from God, they gave everything to God. By continuing to pray to God the patient feels more comfortable.

The researchers also got the same information that the respondents still continued to involve God in the problem. Despite the limitations of practicing worship the respondents claimed to continue to do spiritual activities according to their abilities. Respondents in the study also have a strong goal of recovery. According to Bovero et al. (2013) individuals who truly have a good relationship with God will be more easily adapted to a problem and can find the meaning behind their suffering. Evidently, in the study, most of the respondents had a high life-scheme level, and the average value was higher than the other sub-variables.

Health professionals including nurses are one of the factors that increase the patient's confidence to carry out treatments. This can affect the self-efficacy of the respondents. Respondents claimed believing health professionals who handle them can help in obtaining healing target and increasing confidence to be able to recover. According to Notoatmodjo (2010), available health facilities will affect the desire of patients to carry out treatment.

From this study results, it can be seen that the age of the respondents was in the middle age stage and some of the elderly. According to Hamid (2009) at this stage of development respondents have had philosophical maturity regarding religion and views on the meaning of life. This would help respondents be better prepared to face all the facts that occur. Individuals who have entered this stage of development will accept death as something that cannot be rejected. This condition would help individuals gain peace in their lives so that it can affect their spiritual well-being. 
Most respondents have a high level of spiritual well-being, but a few respondents have a low level of spiritual well-being. From the sub-variables, the sub-variables of self-efficacy have a lower average value compared to the life-scheme sub-variables. Based on the results of the study, the lowest value was seen from the item question; the sub-variable of self-efficacy. Respondents felt that there was not much that could be done to help themselves. This due to physical conditions that are weakened by illness. In addition, the lack of motivation from health care staff, especially nurses who are closest to patients, would also be a cause of low self-confidence in patients.

Almost all respondents claimed that they have never received interventions about the spiritual. The role of nurses can be done in providing nursing care in the spiritual aspect, namely establishing attendance. In addition to providing physical care, nurses can provide encouragement, attention, and a positive attitude that can make patients feel prosperous and give hope to recover from their illness. Another role that can be performed by nurses is to be a motivator for patients. In this case, the nurse must be able to see the emotional, and spiritual condition of the patient in order to help mobilize the patients' expectations to overcome life problems including the illness that they suffered optimally. This would increase self-efficacy in patients (Perry and Potter, 2005).

From the results of this study, the majority of respondents have a high level of spiritual wellbeing, but in the item statement "There is not much I can do to help myself" in the sub-variables of self-efficacy, the majority of respondents have low scores. This is related to how respondents have hope and motivate themselves to do something that can help them from adversity. According to Buckley and Herth (2004), that expectations provide comfort to individuals especially when individuals experience life-threatening situations. Hope is energy that can give 
individuals motivation so that they help patients overcome life stresses. Spiritual well-being can be maximized again if individuals have beliefs about the strength of themselves and God.

Although the level of spiritual well-being is high, spiritual well-being is dynamic, emotive, and subjective. So that at any time the conditions can change significantly (Fisher 2009). This is certainly an important reason for nurses to assess the condition of the patient's spiritual wellbeing, especially patients with terminal diseases such as gynecological cancer. Nurses have an important role to help patients meet their spiritual needs that are part of the holistic needs of patients. Nurses provide care to help meet the spiritual needs of patients by providing adequate facilities for patients to fulfill their spiritual needs. Nurses also provide motivation and enthusiasm to patients so that the quality of life of patients improves even with all the problems they face. These activities must be carried out by nurses even though their beliefs or religions are different from patients (Hamid, 2000). However, in reality, the roles of nurses are still lacking in meeting spiritual needs to improve their spiritual well-being. According to (Wensley, 2008) this may because of nurses are not prepared to deal with the patient's spiritual problems and the nurse considers it as part of psychosocial and is the duty of the priesthood.

A research shows that some nurses feel unable to provide spiritual care to patients as nurses perceived that religion is a personal problem, and an individual relationship with its creator, nurses feel uncomfortable with their religion/beliefs, nurses do not know about spiritual nursing care, nurses carry out needs spiritual for psychosocial needs, and nurses view that fulfilling the patient's spiritual needs is not his responsibility but family responsibilities and religious leaders (Carpenito, 2000).

Based on the results of this study it can be concluded that spiritual well-being in gynecological cancer patients is mostly at a high level. This can occur because of the cultural and 
ethnic background of the respondents who are all Sundanese culture. This custom from the east has high religiosity. So that when experiencing physical problems such as suffering from gynecological cancer patients will be helped by his belief that there is a greater power, namely God who will plan something good for them.

In addition to those mentioned above, family support is one of the triggers for the high spiritual well-being of respondents. The results of the study found that they felt more comfortable when their families accompanied them under any circumstances, and during the research, the respondents were always accompanied by their families.

\section{CONCLUSION AND RECOMMENDATION}

A prosperous spiritual condition can be a source of motivation and enthusiasm in carrying out life in any difficulties. Based on the results that most gynecological cancer patients have a high level of spiritual well-being. The results of the study were obtained in the sub-variables of self-efficacy and sub-variables of life-scheme, most of the respondents had high levels. However, from the average value, the average life-scheme value is higher than self-efficacy. So the presence of nurses to provide motivation to patients is expected to help improve their spiritual well-being. In addition, the presence of nurses in the midst of patients can provide encouragement, attention, and a positive attitude that would make patients feel prosperous and give hope to recover from their illness. Nurses not only carry out nursing care on physical aspects, but the patient's spiritual study is very necessary to support the treatment process and provide welfare to the patient. For the next research, it is expected to conduct a research on the level of spiritual well-being for advanced stage gynecological cancer patients. Weak physical condition and worse prognosis would greatly affect the patient's spiritual condition. 


\section{REFERENCES}

Bekelman. et al. (2009). Symptom Burden, Depression, and spiritual well-being: a comparison of heart failure and advanced cancer patients.

Bovero, A., Leombruni, P., Miniotti, M., \& Torta, R. (2013). Religiosity,pain, and depression in advanced cancer patients. Official Journal of World Association of Cultural Psychiatry, 31-59.

Brunner \& Suddarth. 2013. Keperawatan Medikal-Bedah Brunner \& Suddarth. Jakarta : EGC

Carpenito, L. J. (2000). Diagnosa Keperawatan Aplikasi pada Praktik Klinik. Edisi 6. Jakarta: EGC.

Daaleman, T.P., Frey, B. B., 2004. The Spirituality Index of Well-Being : A New Instrument for Health-Related Quality-of-Life Research

Friedman, M., Bowden, V., \& Jones, E. (2003). Family Nursing: Reasearch Theory \& Practice. New Jersey: Prentice Hall.

Hamid, Achir. 2009. Bunga Rampai Asuhan Keperawatan Jiwa. Jakarta : EGC (2000). Buku Ajar Aspek Spiritual dalam Keperawatan. Jakarta: Widya Medika.

International Agency for Research on Cancer (IARC) / WHO. 2012. GLOBOCAN 2012: Estimated cancer incidence, mortality, and prevalence worldwide in 2012. http://globocan.iarc.fr/Pages/fact_sheets_population.aspx (diakses pada tanggal 14 januari 2016).

Kozier. et al. 2010. Buku Ajar Fundamental Keperawatan : Konsep, Proses, dan Praktik, Edisi 7. Jakarta : EGC 
Mok, E., Wong, F., \&wong, D. (2009). The Meaning of Spirituality and Spiritual Care Among The Hongkong Chinese Terminally Ill. Journal of Advanced Nursing, 360-370.

Nurhalimah, Asti. 2015. Hubungan Kualitas Hidup dengan Kesejahteraan Spiritual pada Pasien Sindrom Koroner Akut di RSUP Dr. Hasan Sadikin Bandung. Fakultas Keperawatan Universitas Padjadjaran

Potter Patricia A \& Perry. 2005. Buku Ajar Fundamental Keperawatan : Konsep, Proses, dan Praktik, Edisi 4. Jakarta : EGC

Puchalski, C. (2001). Spirituality and health: the art of compassionate medicine. Hospital Physician, 37(3), 30-36.

Puchalski, C., Virani, R., Otis-Green, S., Baird, P., Bull, J., Chochinov, H., et al. (2009).Improving the Quality of Spiritual Care as a Dimension of Palliative Care: The Report of the Consensus Conference.Journal of Palliative Medicine, 12(10), 885-904.

Pusat Data dan Informasi. 2015. Buletin Jendela : Data dan Informasi Kesehatan. Jakarta : Kemetrian Kesehatan RI

Richardson, Penny. (2012). Assessment and Implemtation of Spirituality and Religiousity in Cancer Care: Effects on Patient Outcomes. Clinical Journal of Oncology Nursing Vance, Diana L. 2001. Nurses' attitudes towards spirituality and patient care. Medsurg Nursing. Vol. 10. 